\title{
The Vacancy-hardening Properties in Water-quenched Fe-Al Alloys
}

\author{
Z. C. ZHOU ${ }^{\mathrm{a}}$, J. DU ${ }^{\mathrm{b}}$, Y. K. ZHANG ${ }^{\mathrm{s}}$, Y. P. ZHANG ${ }^{\mathrm{d}}$, S. Y. GU
}

School of Mechanical and Electronic Engineering, Suzhou Vocational University, Suzhou, 215104, China

azzc@jssvc.edu.cn, ${ }^{\mathrm{b}} \mathrm{duj} @ j s s v c . e d u . c n,{ }^{\mathrm{c}} z \mathrm{yk} @ j s s v c . e d u . c n,{ }^{\mathrm{d}} z y p @ j s s v c . e d u . c n,{ }^{\mathrm{e}}$ gsy@jssvc.edu.cn

\section{Keywords: Vacancy-hardening, Heat Treatments, Water-quenched Fe-Al Alloys.}

\begin{abstract}
Fe}-\mathrm{Al}$ alloys with different $\mathrm{Al}$ contents were prepared with commercially pure $\mathrm{Fe}$ and $\mathrm{Al}$ in a vacuum induction furnace. The hardness of the $\mathrm{Fe}-\mathrm{Al}$ alloys with different $\mathrm{Al}$ content and heat treatments was measured using a Vickers-hardness tester of HVS-5, applying a load of $9.8 \mathrm{~N}$ and keeping for $8 \mathrm{~s}$. In order to detect the lattice strain of the specimens, X-ray diffraction (XRD) experiments with $\mathrm{CuK}_{\alpha}$ radiation $\left(\lambda=1.5406 \AA\right.$ Á) were completed at room temperature for $\mathrm{Fe}_{62} \mathrm{Al}_{38}$ specimen with different heat treatments. It was shown that the hardness of the furnace-cooled $\mathrm{Fe}-\mathrm{Al}$ alloys increases with increasing $\mathrm{Al}$ content when $\mathrm{Al}$ content is less than 23 (at.)\% $\mathrm{Al}$ and then decreases when more than 23 (at.)\% Al. The furnace-cooled $\mathrm{Fe}_{77} \mathrm{Al}_{23}$ alloy has the largest hardness value among all furnace-cooled alloys. The effect of quenching on the hardness of the $\mathrm{Fe}_{77} \mathrm{Al}_{23}$ and $\mathrm{Fe}_{71} \mathrm{Al}_{29}$ alloys can be obviously observed. The hardness of the $\mathrm{Fe}_{62} \mathrm{Al}_{38}$ alloy increases obviously with increasing quenching temperature. The hardening effect resulted from thermal vacancies can be reduced by the ageing at low temperature.
\end{abstract}

\section{Introduction}

$\mathrm{Fe}-\mathrm{Al}$ alloys contain large numbers of atomic defects such as vacancies and antisite atoms. The defects have great effect on the mechanical and physical properties. Schaefer et al [1-2] studied vacancy features of $\mathrm{Fe}-\mathrm{Al}$ alloys by positron lifetime spectroscopy and mechanical relaxation spectroscopy. Chang et al [3] calculated the vacancy concentration as a function of temperature and Al content. Würschum et al [4] studied the formation and migration of vacancies at high temperatures in $\mathrm{B} 2$-type $\mathrm{Fe}-\mathrm{Al}$ alloys. Indeed, atomic defects in metals or intermetallic compounds under thermal equilibrium play an important role in many solid state processes at high temperature such as order-disorder transition [5], self-diffusion [6] and mechanical creep etc [7]. It is therefore necessary to make clear the effect of the defects for understanding the evolvement of the microstructure and effect of the defects on mechanical properties. From the reported results, quite many researches are focused on the atomic defects, e.g. vacancies, of the $\mathrm{Fe}-\mathrm{Al}$ alloys. Recently, Č́žzek et al [8] investigated the vacancies in $\mathrm{Fe}_{3} \mathrm{Al}$ by positron annihilation and Zhao et al [9] analyzed thermal vacancy behavior in B2-type FeAl through thermal expansion, lattice parameter, and elastic modulus measurements. In addition, there are many researches involved in the relaxation caused by atomic defects in Fe-Al alloys [10-11].

It has been known that concentration of the constitutional defects is sensitive to the alloy composition but is independent of temperature [12] and the concentration of thermal defects, e.g. thermal vacancies have strong dependence on temperature [4]. Nevertheless, it is not completely clear what changes in thermal defects may take place with Al content and heat treatments, and what correlations of the mechanical properties and thermal vacancies (and/or other atomic defects) may exist. The present work presents the variation of the Vickers hardness of Fe-Al alloys with $\mathrm{Al}$ content and heat treatments, finding the correlations among the Vickers hardness, vacancy, Al content in water-quenched Fe-Al alloys.

\section{Experimental Procedure}

Fe-Al alloys with $\mathrm{Al}$ content (at.\%) of 11,17, 23, 29 and 38 (all compositions are described in terms of atomic percent in this article, unless described specially) were prepared with commercially 
pure $\mathrm{Fe}$ and $\mathrm{Al}$ in a vacuum induction furnace. The specimens used in the hardness measurements were cut from the ingots into a dimension $10 \times 10 \times 2 \mathrm{~mm}^{3}$ using an electric sparkle machine. The specimens with different $\mathrm{Al}$ content were heated to $700{ }^{\circ} \mathrm{C}, 800{ }^{\circ} \mathrm{C}, 900{ }^{\circ} \mathrm{C}$ and kept for one hour in an argon atmosphere, followed by water-cooling. In addition, the specimens are also heated for 4 hour at $900^{\circ} \mathrm{C}$ and furnace cooled and the specimen that is water-quenched from $800{ }^{\circ} \mathrm{C}$ is aged at $350{ }^{\circ} \mathrm{C}$ for different time. Specimen surfaces were ground using silicon carbide papers to a 500 grit finish before the hardness of all specimens were measured.

The Vickers-hardness of the specimens with different $\mathrm{Al}$ content and heat treatments was measured using a Vickers-hardness tester of HVS-5, applying a load of $9.8 \mathrm{~N}$ and keeping for $8 \mathrm{~s}$. Standard deviations of Vickers hardness were typically $\pm 3-5 \mathrm{Hv}$. In order to detect the lattice strain change for the $\mathrm{Fe}_{62} \mathrm{Al}_{38}$ specimens with different heat treatments, X-ray diffraction (XRD)

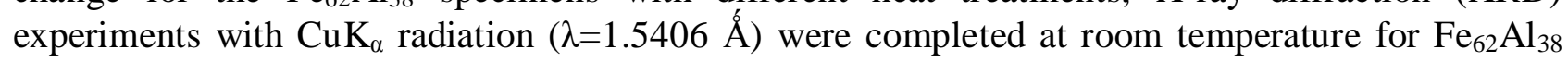
specimen with different heat treatments.

\section{Results and Discussion}

\section{The Variation of Vickers Hardness with Al Content}

Fig. 1 shows the variation of Vickers hardness with $\mathrm{Al}$ content for furnace-cooled Fe-Al specimens. It can be seen that the hardness increases initially with increasing $\mathrm{Al}$ content and decreases when $\mathrm{Al}$ content is over 23(at.)\%. The hardness peak value appears in the furnace-cooled 23 (at.\%)Al alloy. The initial hardness increase is attributed to the effect of solid solution strengthening of $\mathrm{Al}$ on the $\mathrm{Fe}-\mathrm{Al}$ alloys. It is well known that the effect of solid solution strengthening increases with increasing the concentration of solid atoms and therefore the hardness of furnace-cooled $\mathrm{Fe}-\mathrm{Al}$ alloys increases with increasing $\mathrm{Al}$ content. The furnace-cooled $\mathrm{Fe}_{77} \mathrm{Al}_{23}$ alloy has largest hardness value among all alloys with different $\mathrm{Al}$ content, which is similar to the results reported by Hasemann et al [13], who found the maximum of yield stress occurs in the slow-cooled specimen with 25 (at.\%) Al. When $\mathrm{Al}$ content is over 23 (at.\%), the hardness is reduced for the furnace-cooled $\mathrm{Fe}-\mathrm{Al}$ alloys. According to Ref. [14], the dilute $\mathrm{Fe}-\mathrm{Al}$ alloys with the $\mathrm{Al}$ content from 0 to $22 \%$ are intrinsically disordered A2 structure according to $\mathrm{Fe}-\mathrm{Al}$ phase diagram. When $\mathrm{Al}$ content is located between 23 and 36 (at. \%), the ordered $\mathrm{Fe}_{3} \mathrm{Al}$ with $\mathrm{D}_{3}$ structure can be formed and ordered $\mathrm{DO}_{3}$ structure can enhance the hardness of $\mathrm{Fe}$-Al alloys. The deviation from stoichiometry can in principle be compensated for either by vacancy or by antisite atom [15]. For $\mathrm{D}_{3} \mathrm{Fe}_{3} \mathrm{Al}$, on one hand, structural defects on the rich-Fe side are $\mathrm{Fe}$ antisite atoms and on the rich-Al side are $\mathrm{Al}$ antisite atoms for the furnace-cooled alloys due to little thermal defects. Therefore, the furnace-cooled $\mathrm{Fe}_{77} \mathrm{Al}_{23}$ alloy has higher hardness value than $\mathrm{Fe}_{71} \mathrm{Al}_{29}$ alloy since the former contains $\mathrm{Fe}$ antisite atoms and the latter has $\mathrm{Al}$ antisite atoms for the two alloys with the same $\mathrm{DO}_{3}$ structure. More $\mathrm{Al}$ antisite atoms decrease the hardness of $\mathrm{Fe}_{71} \mathrm{Al}_{29}$ alloy since $\mathrm{Al}$ has smaller hardness than Fe. In addition, From Table 1, it can be seen that heating temperature has smaller effect on the hardening of the water-quenched alloys with lower Al content since the water-quenched alloys with lower $\mathrm{Al}$ content have less vacancy concentration.

Tab. 1 The Vickers Hardness Values of Specimens with Different Al Concentration and Heat Treatment

\begin{tabular}{c|ccccc}
\hline & \multicolumn{5}{|c}{ Vickers hardness (MPa) } \\
\hline $\mathrm{Al}($ at. \%) & $700{ }^{\circ} \mathrm{C}-\mathrm{WQ}^{*}$ & $800{ }^{\circ} \mathrm{C}-\mathrm{WQ}$ & $900{ }^{\circ} \mathrm{C}-\mathrm{WQ}$ & $900{ }^{\circ} \mathrm{C}-\mathrm{FC}$ & $350{ }^{\circ} \mathrm{C}-20 \mathrm{~h}$-aged \\
\hline 11 & 193 & 199 & 196 & 200 & \\
17 & 267 & 280 & 281 & 299 & 340 \\
23 & 303 & 309 & 317 & 351 & \\
29 & 283 & 299 & 308 & 284 & \\
38 & 313 & 381 & 411 & 276 & \\
\hline
\end{tabular}

* WQ denotes water quenching and FC denotes furnace cooling 
Fig. 2 present the variation of Vickers hardness with Al contents for the water-quenched specimens. It can be seen that the hardness of the specimens increases with increasing $\mathrm{Al}$ contents when $\mathrm{Al}$ content is less than about 23 (at.\%).

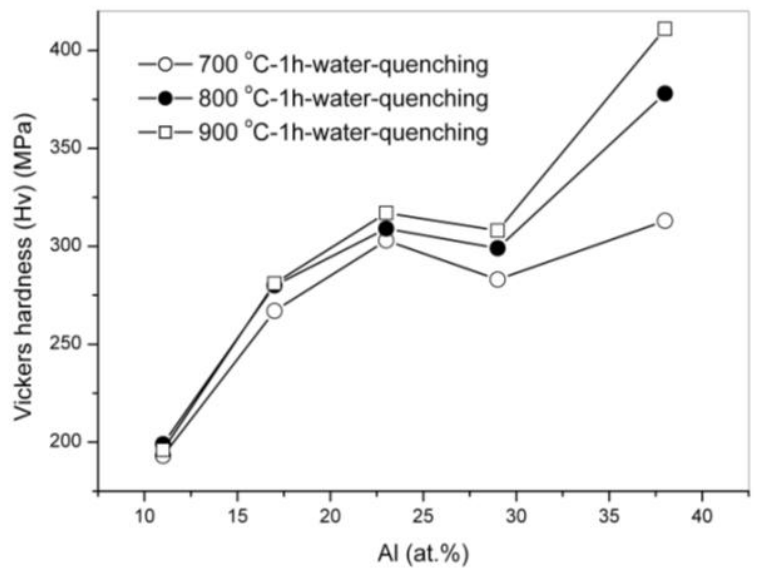

Fig. 1 The Variation of Vickers Hardness with Al Content for Furnace-cooled Fe-Al Specimens

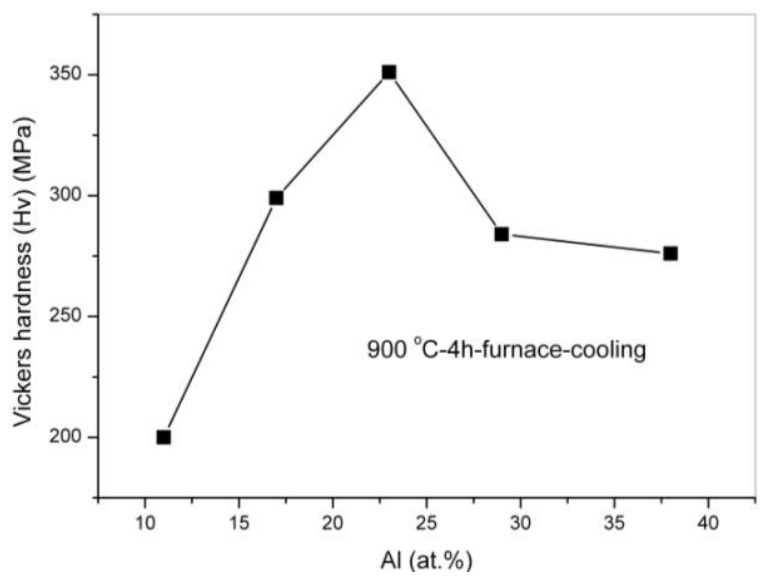

Fig. 2 The Variation of Vickers Hardness with Al Content for Water-quenched Fe-Al Specimens from Different Temperature

From Figs. 1, 2 and Table 1, it can also be seen that the Vickers hardness of the furnace-cooled $\mathrm{Fe}_{77} \mathrm{Al}_{23}$ alloy has the higher value than the water-quenched specimens with the same chemical compositions. This is attributed to the increase of order degree in the furnace-cooled. $\mathrm{DO}_{3}$ structure formed during the furnace-cooling possesses higher hardness than A2 structure. According to Ref. [16], $\mathrm{D}_{3}$ ordering treatment is generally carried out in the temperature range from $200{ }^{\circ} \mathrm{C}$ to $500{ }^{\circ} \mathrm{C}$. Further investigation shows the aging at low temperature for long time has the similar effect to the furnace-cooling from high temperature. The Vickers hardness value can be increased to $340 \mathrm{MPa}$ by the ageing at $350{ }^{\circ} \mathrm{C}$ for 20 hours for the $\mathrm{Fe}_{77} \mathrm{Al}_{23}$ alloy.

In addition, it can be noticed that the $\mathrm{Fe}-\mathrm{Al}$ alloys with the compositions in the vicinity of $\mathrm{Fe}-25$ at.\% Al can hardly be strengthened by the water-quenching. The Vickers hardness is increased a little for the water-quenched $\mathrm{Fe}_{77} \mathrm{Al}_{23}$ and $\mathrm{Fe}_{71} \mathrm{Al}_{29}$ alloys compared with the furnace-cooled alloys. However, the hardness of the $\mathrm{Fe}_{62} \mathrm{Al}_{38}$ alloy with $\mathrm{B} 2$ structure increases drastically with increasing quenching temperature, as shown in Fig. 1. The hardness increase is resulted from the thermal vacancy-hardening. The vacancy concentration in $\mathrm{Fe}_{77} \mathrm{Al}_{23}$ and $\mathrm{Fe}_{71} \mathrm{Al}_{29}$ with potential $\mathrm{D0}_{3}$ structure is much smaller than that of the $\mathrm{Fe}_{62} \mathrm{Al}_{38}$ alloy with $\mathrm{B} 2$ structure according to Refs. [15-18]. It has been known that the vacancy concentration in materials increases with increasing temperature and the hardness will be increased if the vacancies is retained by the quenching. Therefore, the Vickers hardness increases with increasing quenching temperature.

It is easily understood that the lattice constant is reduced when the vacancies are introduced into the alloys. The reduction in lattice constants will shift the diffraction peak to higher angle according to Bragg law in X-ray diffraction experiments [19]. According to Ref. [20], the relation of the lattice strain and the diffraction angle can be described as the following equation:

$$
\frac{\beta_{h k l}^{2}}{\tan ^{2} \theta_{h k l}}=\frac{\lambda \beta_{h k l}}{D_{h k l} \tan \theta_{h k l}}+16<\varepsilon_{h k l}^{2}>^{\frac{1}{2}}
$$

Where, $\lambda$ is wavelength of $\mathrm{Cu} \mathrm{K} \alpha$ radiation. $D_{h k l}$ and $\left\langle\varepsilon_{h k l}^{2}\right\rangle^{\frac{1}{2}}$ is grain size and lattice strain on $<h k l>$ direction, respectively. $\beta_{h k l}$ is a width coefficient and $\theta_{h k l}$ is diffraction angle on $<h k l>$ direction. From equation (1), it can be also seen that the $\left\langle\varepsilon_{h k l}^{2}>^{\frac{1}{2}}\right.$ is related to $\theta_{h k l}$. The present 
experiments are in agreement with Refs. [20-21].From Fig. 2, the (110) diffraction peak of the water-quenched $\mathrm{Fe}_{62} \mathrm{Al}_{38}$ alloy is shifted to higher angle compared with the furnace-cooled $\mathrm{Fe}_{62} \mathrm{Al}_{38}$ alloy since the water-quenched $\mathrm{Fe}_{62} \mathrm{Al}_{38}$ alloy contains large numbers of vacancies, which reduces the lattice constants and increases the diffraction angle. From Fig. 2, it can also be seen that curve 2 in Fig. 2 is a little not symmetric obviously. This asymmetry can be resulted from the heterogeneity of lattice strain caused by vacancies.

\section{The Variation of Vickers Hardness with Aging Time}

Generally, the thermal vacancies can be annihilated when the quenched specimens are aged at low temperature. Fig. 3 and Table 2 show the hardness variation of the $800{ }^{\circ} \mathrm{C}$-water-quenched $\mathrm{Fe}_{62} \mathrm{Al}_{38}$ alloy with ageing time at $350{ }^{\circ} \mathrm{C}$ [16-17]. It can be seen that the hardness decreased with increasing the ageing time. It has been reported that the vacancy annihilation can produces dislocation in $\mathrm{B} 2 \mathrm{FeAl}$ alloys, which has a little contribution to hardness [16], indicating that the vacancy-hardening is reduced and the vacancy concentration is gradually decreased. Further investigation shows the hardness of the water-quenched $\mathrm{Fe}_{62} \mathrm{Al}_{38}$ alloy from $900{ }^{\circ} \mathrm{C}$ is decreased from $411 \mathrm{Hv}$ to $307 \mathrm{Hv}$ when aged at $400{ }^{\circ} \mathrm{C}$ for 2.5 hours, indicating that higher ageing temperature has stronger reducing effect on hardness under the same ageing time.
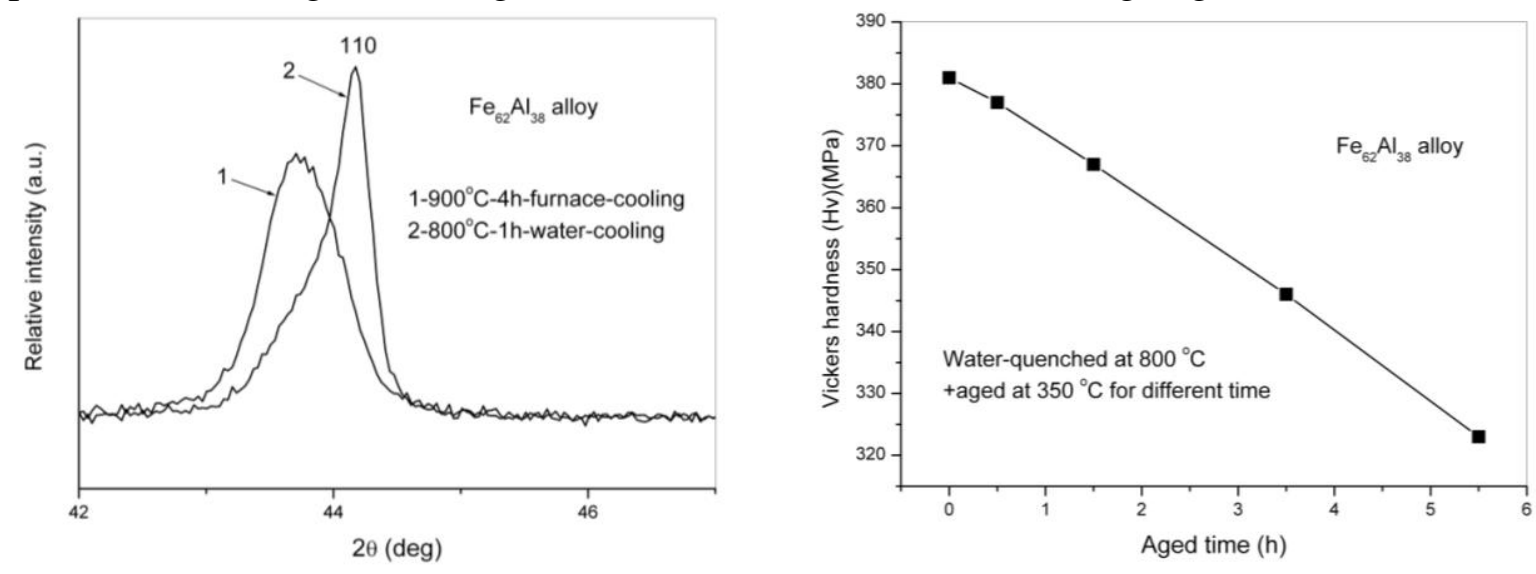

Fig. 3 The X-ray Profiles of the Water-quenched Fig. 4 The Variation of Hardness with Ageing Time and Furnace-cooled $\mathrm{Fe}_{62} \mathrm{Al}_{38}$ Specimens for the Water-quenched $\mathrm{Fe}_{62} \mathrm{Al}_{38}$ Alloy from $800{ }^{\circ} \mathrm{C}$

Tab.2 The Vickers Hardness Values of Water-quenched $\mathrm{Fe}_{62} \mathrm{Al}_{38}$ Specimens from $800{ }^{\circ} \mathrm{C}$ at Different Aging Time

\begin{tabular}{c|ccccc}
\hline Aging time (h) & 0 & 0.5 & 1.5 & 3.5 & 5.5 \\
\hline Hardness (MPa) & 381 & 377 & 367 & 346 & 323 \\
\hline
\end{tabular}

\section{Conclusions}

The hardness of the furnace-cooled Fe-Al alloys increases with increasing $\mathrm{Al}$ content when $\mathrm{Al}$ content is less than 23 (at.)\% $\mathrm{Al}$ and then decreases when more than 23 (at.)\% Al. The furnace-cooled $\mathrm{Fe}_{77} \mathrm{Al}_{23}$ alloy has the largest hardness value among all furnace-cooled alloy, which is attributed to the ordered $\mathrm{DO}_{3}$ structure and the effect of solid solution hardening. The effect of quenching on the hardness of the $\mathrm{Fe}_{77} \mathrm{Al}_{23}$ and $\mathrm{Fe}_{71} \mathrm{Al}_{29}$ alloys can be obviously observed since they have low thermal vacancy concentration compared with $\mathrm{Fe}_{62} \mathrm{Al}_{38}$ with $\mathrm{B} 2$ structure. The hardness of the $\mathrm{Fe}_{62} \mathrm{Al}_{38}$ alloy increases obviously with increasing quenching temperature. This increase in hardness is attributed to the strengthening effect of thermal vacancy resulted from quenching. The introduction of thermal vacancy cause lattice constant to reduce and the diffraction angle is shifted to larger angle. The hardening effect resulted from thermal vacancies can be reduced by the ageing at low temperature. 


\section{Acknowledgements}

This work is sponsored by Qing Lan Project of Jiangsu and supported by research foundation of Suzhou Vocational University (2013SZDYJ05).

\section{References}

[1]H.-E Schaefer, B. Damson, E. Weller, E. Arzt and E. P. George: phys. stat. sol. (a) 160 (1997), 531-540.

[2]H.-E Schaefer, K. Frenner and R. Wurschum: Phys. Rev. Lett. 82 (1999), 948-951.

[3]Y. A. Chang, L. M. Pike, C. T. Liu, A. R. Bilbrey and D. S. Stone: Intermetallics 1 (1993), 107-115.

[4]R. Würschum, C. Grupp and H.-E Schaefer: Phys. Rev. Lett. 75 (1995), 97-100.

[5]O. Dimitrov, in: Intermetallic Compounds-Principles and Practice, (ed. J. H. Westbrook et al.), John Wiley, Chichester, Vol.1 (1994), p.771.

[6]Y. Mishin et al (ed.):Diffusion Mechanisms in Crystalline Material, MRS Symposia Proceedings, No.527, Materials Research Society, Pittsburgh (1998).

[7]G. Sauthoff, in: Diffusion in Ordered Alloys, (ed. B. Fultz et al.), TMS, Warrendale (1993), p.205.

[8]J. Čížek, F. Kukáč, O. Melikhova, I. Procházka, R. Kužel: Acta Meter. 59 (2011), 4068-4078.

[9]M. Zhao, K. Yoshimi, K. Maruyama, K. Yubuta: Acta Meter. 64 (2014), 382-390.

[10]Z. C. Zhou, Z. Y. Gao and F. S. Han: Journal of Physics: Condensed Matter.15 (2003), 6809-6815.

[11]Z. C. Zhou, F. S. Han and Z. Y. Gao: Acta Mater. 52 (2004), 4049-4054.

[12]A. S. Nowick and B. S. Berry: Anelastic Relaxation in crystalline solids, New York and London, Academic Press (1972).

[13]G. Hasemann, J. H Schneibel, M. Krüger, E. P. George: Intermetallics 54 (2014), 95-103.

[14]O. Kubaschewski: Iron-Binary Phase Diagrams, Berlin, Springer-Verlag (1982).

[15]M. Eggersmann and H. Mehrer: Phil. Mag. A 80 (2000), 1219-1244.

[16]D. G. Morris, M. Leboeuf, S. Gunther and M. Nazmy: Phil. Mag. A 70 (1994),1067-1090.

[17]M. A. Morris, O. George, D. G. Morris: Mater. Sci. Eng. A 258 (1998), 99-107.

[18]M. A. Morris, D. G. Morris: Scripta Metall.38 (1998), 509-516.

[19]R. Jenkins, et al: Quantitative X-ray Spectrometry, New York (1979).

[20]E. P. Bertin: Principles and Practice of X-ray Spectrometric Analysis, New York-London, Plenum Press(1975).

[21]H. P. Klug, L. E. Alexander: X-ray diffraction procedures for poly-crystalline and amorphous materials, second edition, New York, John Wiley and Sons, (1974), p.491. 